\title{
Pengaruh Brand Ambassaddor Didi Kempot terhadap Citra Perusahaan Shopee
}

\author{
Cindy $^{1}$, H.H Daniel Tamburian* \\ ${ }^{1}$ Fakultas Ilmu Komunikasi Universitas Tarumanagara, Jakarta \\ Email: cindy915170016@stu.untar.ac.id \\ ${ }^{2}$ Fakultas Ilmu Komunikasi Universitas Tarumanagara, Jakarta* \\ Email:danielt@fikom.untar.ac.id
}

Masuk tanggal : 15-12-2021, revisi tanggal : 06-01-2022, diterima untuk diterbitkan tanggal : 16-02-2022

\begin{abstract}
The era of advanced change is showing the rapid growth of the internet. It also applies to ecommerce development in Indonesia. There are many ways used by e-commerce companies in the hope of surviving the competition of one another, one of the strategies is using the brand ambassaddor to help the companies to build their corporate image. The strategy that Shopee used to appoint the Brand ambassaddor is with the purpose to communicate and represent a certain product as well as to build the company identity. this research aims to determine the impact of Didi Kempot as the brand ambassaddor to the corporate image of Shopee. The theories used in this research are brand ambassaddor, corporate image and public relations. This research used quantitative methods with a survey method. The technique in this study uses non-probability sampling using a purposive sampling approach, the data collection techniques used are by using questionnaire of 100 respondents and literature study. The result of simple linear regression returns a positive constant, which means if there is an increase in brand ambassaddor variable then the corporate image will also be increased. The result of Pearson correlation analysis of the two variables has the moderate degree between brand ambassaddor Didi Kempot to the corporate image of Shopee with 0.581 as the correlation value. The conclusion of this research is that the brand ambassaddor has a significant impact on the corporate image of Shopee.
\end{abstract}

Keywords: brand ambassaddor, corporate image, public relations

\begin{abstract}
Abstrak
Perubahan zaman yang semakin maju memperlihatkan adanya kemajuan internet yang begitu cepat, sehingga e-commerce di Indonesia pun turut ikut serta dalam perkembangan tersebut. Berbagai cara dilakukan oleh setiap perusahaan e-commerce dengan cepat untuk bisa bertahan dan bersaing, salah satunya yaitu memakai brand ambassaddor untuk membantu perusahaan dalam membentuk citranya. Strategi yang dilakukan oleh Shopee sendiri dalam menggunakan brand ambassaddor memiliki tujuan untuk membentuk sebuah identitas dan mengkomunikasikan atau merepresentasikan suatu produk dari sebuah perusahaan. Tujuan yang ingin dicapai dalam penelitian ini yaitu untuk mengetahui apakah terdapat pengaruh brand ambassaddor Didi Kempot terhadap citra perusahaan Shopee. Dalam penelitian ini menggunakan teori brand ambassaddor, citra perusahaan dan public relations. Penelitian ini memakai metode kuantitatif dengan jenis metode survei. Teknik dalam penelitian ini menggunakan non-probability sampling dengan memakai pendekatan purposive sampling, Teknik pengumpulan data pada penelitian ini menggunakan kuesioner pada 100 responden dan studi kepustakaan. Hasil dari uji regresi linier sederhana bernilai positif dalam konstanta, artinya jika ada peningkatan pada variabel brand ambassaddor maka citra perusahaan juga meningkat. Hasil uji korelasi pearson kedua variabel memiliki tingkat hubungan sedang antara brand ambassaddor Didi Kempot terhadap citra perusahaan Shopee dengan nilai korelasi
\end{abstract}


0,581. Kesimpulan dari penelitian ini menyatakan bahwa brand ambassaddor memiliki pengaruh yang signifikan terhadap citra perusahaan Shopee.

Kata Kunci: brand ambassaddor, citra perusahaan, public relations

\section{Pendahuluan}

Perusahaan E-commerce biasanya memiliki brand ambassaddor untuk mempresentasikan perusahaannya guna mencapai citra yang diinginkan. Penggunaan brand ambassaddor (selebritas misalnya) tidak lepas dari prestasi yang dimiliki oleh selebritas itu sendiri, umumnya perusahaan akan memilih selebriti yang sedang naik daun atau disenangi dalam masyarakat karena prestasi yang diperoleh maupun karena kepribadian selebriti itu sendiri.

Hasil penelitian terdahulu yang dilakukan oleh Raswen, Rima (2019) menemukan bahwa pengaruh brand ambassaddor BLACKPINK Terhadap Citra perusahaan Shopee diketahui besarnya nilai thitung $(4,476)>$ ttab el $(1,98)$ dengan nilai signifikasi yang dihasilkan sebesar 0,000 masih berada dibawah 0,05 , maka hipotesis dalam penelitian ini diterima. Hal ini menjelaskan bahwa terdapat pengaruh brand ambassaddor BLACKPINK (variabel X) terhadap Citra perusahaan Shopee (variabel Y) Pada Mahasiswi di UIN Suska Riau.

Penggunaan brand ambassaddor yang dilakukan oleh berbagai platform ecommerce sebagai ikon atau simbol untuk menjadi mrepresentasikan produk atau perusahaan. Salah satu perusahaan yang bersangkutan adalah Shopee. Shopee merupakan sebuah e-commerce yang berjalan di bidang komersial secara online dan shopee juga memiliki aplikasi yang dapat diakses secara mudah dan sederhana dengan menggunakan smartphone.

Membuka awal tahun 2020 YouGov Brand Index menobatkan Shopee sebagai peringkat pertama dalam kategori Top Buzz Rankings. Shopee mendapatkan prestasi dari YouGov Brand Index yang merupakan sebuah perusahaan riset pasar yang berada di London. Shopee dapat dinobatkan sebagai kategori tersebut karena banyak melakukan berbagai ide kreatif yang menarik sebagai brand e-commerce dalam mendekatkan diri dengan keinginan masyarakat Indonesia secara online (sumber: kontan.co.id).

Strategi yang dilakukan oleh Shopee sendiri dalam mengangkat brand ambassaddor yaitu untuk mengkomunikasikan atau merepresentasikan yang dapat membentuk personalitas sebuah perusahaan. Brand ambassaddor merupakan komunikator yang menyampaikan pesan mengenai citra yang diharapkan. Komunikator memiliki peran yang penting dalam menunjang keberhasilan suatu kegiatan komunikasi. Menurut Poghosyan (2015:32) brand ambassaddor adalah orang yang bergabung dengan suatu merek dan menjadi representatif dari merek tersebut.

Salah satu cara untuk melihat kelebihan brand ambassaddor yang menjadi seorang komunikator dari sebuah perusahaan yaitu dengan teori brand ambassaddor. Teori brand ambassaddor memiliki empat karakteristik yaitu Visibility, Credibility, Attraction dan Power. Visibility sendiri memiliki dimensi seberapa jauh popularitas seorang selebriti, Credibility merupakan pengetahuan selebriti mengenai produk yang dipasarkan, Attraction merupakan daya tarik selebriti itu sendiri, Power adalah kemampuan selebriti dalam menarik konsumen untuk membeli (Royan, 2005:15).

Penggunaan selebriti sebagai brand ambassaddor pada e-commerce Shopee yaitu dengan adanya ketenaran dan kepopuleran mereka dapat mempengaruhi dan mendorong publik dan konsumen untuk membantu membentuk citra yang diinginkan 
Cindy, H.H Daniel Tamburian: Pengaruh Brand Ambassaddor Didi Kempot terhadap Citra Perusahaan Shopee

oleh perusahaan. Harrison (Iman, 2010) menyatakan bahwa pembentukan Citra perusahaan memiliki empat elemen yaitu personality, reputation, value dan corporate Identity.

Mengangkat konsep budaya Indonesia, pada Desember 2019 Shopee menggandeng brand ambassaddor terbaru dengan berkolaborasi bersama Didi Kempot sebagai "brand ambyarssador". Shopee menyebut Didi sebagai Brand Ambyarsador karena kata tersebut gabungan dari "ambassaddor" dan "ambyar". Melalui karya-karya musik tradisional Jawa yang dibawakan Didi kempot dapat menarik dan menjadi sosok yang dekat dengan masyarakat, sehingga memiliki penggemar yang sangat banyak dan sangat berantusias. Didi Kempot merupakan penyanyi yang berprestasi dan jauh dari gosip yang tidak baik namun Didi Kempot meninggal pada 5 Mei 2020 pada saat masih menjadi brand ambassaddor.

Dengan adanya keunikan dengan menggunakan Didi Kempot sebagai brand ambassaddor dapat berdampak pada citra perusahaan Shopee di mata konsumen. Dalam membentuk reputasi dan prestasi perusahaan yang hendak dicapai, citra merupakan tujuan utama yang ingin dibentuk dari seorang public relations. Menurut Bill Canton (dalam Soemirat \& Ardianto. E, 2007), citra perusahaan adalah kesan, perasaan, gambaran dari masyarakat atau publik terhadap perusahaan, kesan yang dengan sengaja diciptakan dari suatu suatu objek, orang atau organisasi.

Sebuah perusahaan memiliki hal yang harus diutamakan yaitu citra dari perusahaan, citra menjadi sangat penting terhadap keberlangsungan hidup suatu perusahaan dengan demikian dalam menentukan brand ambassaddor tentu harus dilatarbelakangi citra yang positif. Penelitian ini memiliki rumusan masalah yaitu "Apakah terdapat pengaruh brand ambassaddor Didi Kempot terhadap citra perusahaan Shopee?" maka adapun tujuan yang ingin di capai dalam penelitian ini yaitu untuk mengetahui apakah terdapat hubungan antara brand ambassaddor Didi Kempot terhadap citra perusahaan Shopee dan untuk mengetahui apakah terdapat pengaruh dari brand ambassaddor Didi Kempot terhadap citra perusahaan Shopee.

\section{Metode Penelitian}

Penelitian ini memakai pendekatan kuantitatif, pendekatan kuantitatif (Creswell, 2014:5) adalah metode untuk menguji teori-teori tertentu dengan cara meneliti hubungan antar variabel, dimana variabel-variabel tersebut dapat diukur dengan instrumen penelitian dan data yang dianalisis terdiri dari angka-angka yang dapat dianalisis menggunakan ilmu statistik.

Pada penelitian ini peneliti memilih pendekatan kuantitatif dengan metode survei. Karena menurut Sugiyono (2017:6), metode survei merupakan metode yang digunakan untuk mendapatkan data dari tempat tertentu yang alamiah (bukan buatan), tetapi peneliti melakukan perlakuan dalam pengumpulan data, misalnya dengan mengedarkan kuesioner, test, wawancara terstruktur dan sebagainya.

Dalam penelitian ini peneliti menggunakan populasi dengan kriteria pengguna aplikasi Shopee yang mengetahui Didi Kempot sebagai brand ambassaddor dan pernah melihat iklan Shopee dengan Didi Kempot sebagai bintang iklan. Berdasarkan data yang telah diakses melalui channel youtube Shopee Indonesia, diakses pada 11 November 2020 iklan yang menggunakan Didi Kempot sebagai bintang iklan dan juga brand ambassaddor bersama Shopee yang diunggah oleh Shopee dan telah ditonton sebanyak kurang lebih 5,2 juta viewers. 
Jumlah sampel yang akan digunakan pada penelitian ini yaitu ditentukan dengan rumus Slovin menurut (Sugiyono, 2018). Dari rumus tersebut menghasilkan sampel sebanyak 100 responden untuk berpartisipasi dalam penelitian. Menyebarkan kuesioner dengan menggunakan google form. Penelitian ini menggunakan teknik penentuan sampel yang berdasarkan pada metode non-probability sampling (Sugiyono, 2017:84), dengan memakai pendekatan purposive sampling merupakan penentuan sampel untuk pertimbangan tertentu.

Data yang didapat dari penyebaran kuesioner kemudian dianalisis dengan menggunakan skala Likert. Penelitian ini menggunakan data dari kuesioner dan juga menggunakan studi kepustakaan untuk menambah referensi dan informasi untuk membahas penelitian. Pada penelitian ini keabsahan data yang peneliti gunakan adalah uji validitas, uji reliabilitas, dan uji normalitas. Sedangkan untuk pengolahan dan analisis data memakai uji koefisien korelasi pearson, analisis regresi linier sederhana, dan uji T.

Gambar 1. Kerangka Pemikiran

\begin{tabular}{|c|c|}
\hline Brand Ambassador $(\mathbf{X})$ & Citra Perusahaan (Y) \\
Visibility & Personality \\
Credibility & Reputation \\
Attraction & Value \\
Power & Corporate identity \\
\hline
\end{tabular}

Sumber: Olahan Data Peneliti

Berdasarkan dari gambar diatas maka kerangka pemikirian dalam penelitian ini menghasilkan hipotesis:

Ha: terdapat pengaruh brand ambassaddor Didi Kempot terhadap citra perusahaan Shopee.

Ho: tidak terdapat pengaruh brand ambassaddor Didi Kempot terhadap citra perusahaan Shopee.

\section{Hasil Temuan dan Diskusi}

Dari hasil penelitian yang diperoleh menyatakan bahwa dari 100 responden terdiri dari laki-laki dengan presentase $35 \%$ dan perempuan dengan presentase $65 \%$ sehingga responden dalam penelitian ini mayoritas adalah perempuan. Dapat diketahui juga dalam segi usia, sebagian besar responden berusia 21 tahun. Rata-rata responden berdomisili di Jakarta Barat.

Dari hasil pengolahan data, nilai rata-rata penilaian responden dalam variabel brand ambassaddor dimensi tertingginya adalah visibility, sehingga dalam dimensi ini citra perusahaan Shopee yang sangat mempengaruhi. Untuk nilai rata-rata penilaian responden pada variabel citra perusahaan aspek tertingginya adalah corporate identity dalam mempengaruhi citra perusahaan Shopee. 
Setelah melakukan proses pengolahan data melalui 100 responden, peneliti menggunakan teknik keabsahan data dengan melakukan uji validitas, uji reliabilitas, dan uji normalitas pada 20 pernyataan dalam kuesioner.

Tabel 1. Hasil Uji Validitas

\begin{tabular}{cccc}
\hline No. Soal & $\begin{array}{c}\text { Corrected Item-Total } \\
\text { Correlation }\end{array}$ & Nilai & Keterangan \\
\cline { 2 - 3 } P1 & 0.676 & 0,2 & Valid \\
P2 & 0.748 & 0,2 & Valid \\
P3 & 0.720 & 0,2 & Valid \\
P4 & 0.556 & 0,2 & Valid \\
P5 & 0.698 & 0,2 & Valid \\
P6 & 0.608 & 0,2 & Valid \\
P7 & 0.824 & 0,2 & Valid \\
P8 & 0.752 & 0,2 & Valid \\
P9 & 0.749 & 0,2 & Valid \\
P10 & 0.767 & 0,2 & Valid \\
P11 & 0.651 & 0,2 & Valid \\
P12 & 0.509 & 0,2 & Valid \\
P13 & 0.680 & 0,2 & Valid \\
P14 & 0.605 & 0,2 & Valid \\
P15 & 0.736 & 0,2 & Valid \\
P16 & 0.669 & 0,2 & Valid \\
P17 & 0.685 & 0,2 & Valid \\
P18 & 0.492 & 0,2 & Valid \\
P19 & 0.580 & 0,2 & Valid \\
P20 & 0.606 & 0,2 & Valid \\
\hline S4 & & &
\end{tabular}

Sumber: Olahan Data Peneliti

\section{Uji Reliabilitas X}

Hasil dari uji reliabilitas melalui SPSS 20 menunjukan bahwa 10 butir pernyataan variabel X (Brand Ambassaddor) menghasilkan nilai Cronbach's Alpha sebesar 0,922 artinya bahwa pada variabel brand ambassaddor memiliki instrumen yang reliabel sehingga variabel tersebut dapat dipercaya karena memiliki nilai Cronbach's Alpha yang lebih besar dari 0,6 yaitu 0,922 >0,6.

\section{Uji Reliabilitas Y}

Hasil dari uji reliabilitas melalui SPSS 20 menunjukkan bahwa 10 butir pernyataan dari variabel Y (Citra perusahaan) menghasilkan nilai Cronbach's Alpha sebesar 0,883 yang artinya variabel citra perusahaan memiliki instrumen yang reliabel artinya variabel tersebut dapat dipercaya karena memiliki nilai Cronbach's Alpha yang lebih besar dari 0,6 yaitu 0,883>0,6. 


\section{Uji Normalitas}

Hasil yang diperoleh dari uji normalitas menunjukan adanya nilai yang signifikan sebesar 0,442 , karena menghasilkan nilai signifikansi yang lebih besar dari 0,05 maka dapat disimpulkan bahwa data dalam penelitian ini dapat dinyatakan normal.

\section{Uji Koefisien Korelasi Pearson}

Tabel 2. Koefisien Korelasi Pearson

Correlations

\begin{tabular}{|c|c|c|c|}
\hline & & $\begin{array}{c}\text { Brand } \\
\text { Ambassaddor }\end{array}$ & Citra Perusahaan \\
\hline \multirow{3}{*}{$\begin{array}{l}\text { Brand } \\
\text { Ambassaddor }\end{array}$} & $\begin{array}{l}\text { Pearson } \\
\text { Correlation }\end{array}$ & 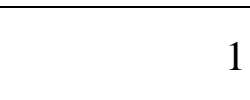 & $.581^{* *}$ \\
\hline & Sig. (2-tailed) & & .000 \\
\hline & $\mathrm{N}$ & 100 & 100 \\
\hline \multirow{3}{*}{ Citra Perusahaan } & $\begin{array}{l}\text { Pearson } \\
\text { Correlation }\end{array}$ & $.581^{* *}$ & 1 \\
\hline & Sig. (2-tailed) & .000 & \\
\hline & $\mathrm{N}$ & 100 & 100 \\
\hline
\end{tabular}

. Correlation is significant at the 0.01 level (2-tailed).

Sumber: Olahan Data Peneliti

Hasil yang didapat dari uji korelasi pearson variabel X (brand ambassaddor) dan variabel Y (citra perusahaan) pada penelitian ini sebesar 0,581. Menurut Sugiyono (2017:231), Jika hasil interval koefisien sebesar 0,40-0,599 maka menghasilkan tingkat hubungan antara variabel $\mathrm{X}$ (brand ambassaddor) dan variabel $\mathrm{Y}$ (citra perusahaan) dalam penelitian ini adalah sedang.

\section{Koefisien Determinasi}

Tabel 3. Koefisien Determinasi Model Summary

\begin{tabular}{lcccr}
\hline Model & R & R Square & $\begin{array}{c}\text { Adjusted R } \\
\text { Square }\end{array}$ & $\begin{array}{l}\text { Std. Error of } \\
\text { the Estimate }\end{array}$ \\
\hline 1 & $.581^{\mathrm{a}}$ & .337 & .331 & 4.788 \\
\hline a|. Predictors: (Constant), Brand Ambassaddor & \\
\hline \multicolumn{4}{l}{ Sumber: Olahan Data Peneliti } &
\end{tabular}

Dapat dilihat pada tabel diatas, hasil yang diperoleh dari koefisien determinasi yaitu R Square memiliki nilai 0,337, hal ini dapat dinyatakan bahwa kemampuan dari variabel independen dalam mempengaruhi variabel dependen adalah lemah karena nilai koefisien determinasi mendekati nol. Sehingga dapat dinyatakan bahwa citra perusahaan Shopee dipengaruhi sebesar 33,7\% oleh brand ambassaddor, sementara sisanya sebesar $66,3 \%$ dipengaruhi oleh variabel dan faktor lain. 
Cindy, H.H Daniel Tamburian: Pengaruh Brand Ambassaddor Didi Kempot terhadap Citra Perusahaan Shopee

\section{Analisis Regresi Linier Sederhana}

Tabel 4. Analisis Regresi Linier Sederhana dan Uji T

\section{Coefficients $^{\mathbf{a}}$}

\begin{tabular}{|c|c|c|c|c|c|c|}
\hline \multirow{2}{*}{\multicolumn{2}{|c|}{ Model }} & \multicolumn{2}{|c|}{$\begin{array}{c}\text { Unstandardized } \\
\text { Coefficients }\end{array}$} & \multirow{2}{*}{$\begin{array}{l}\text { Standardized } \\
\text { Coefficients } \\
\text { Beta }\end{array}$} & \multirow[t]{2}{*}{$\mathrm{t}$} & \multirow[t]{2}{*}{ Sig. } \\
\hline & & $\mathrm{B}$ & $\begin{array}{l}\text { Std. } \\
\text { Error }\end{array}$ & & & \\
\hline & (Constant) & 21.955 & 2.812 & & 7.808 & .000 \\
\hline 1 & $\begin{array}{l}\text { Brand } \\
\text { Ambassaddor }\end{array}$ & .490 & .069 & .581 & 7.064 & .000 \\
\hline
\end{tabular}

a. Dependent Variable: Citra Perusahaan

Sumber: Olahan Data Peneliti

$$
\mathbf{Y}=\mathbf{a}+\mathbf{b X}
$$

Setelah diuji, maka hasil konstanta sebesar 21,955 memiliki arti bahwa jika tidak ada kenaikan variabel X (Brand ambassaddor) maka nilai konsisten variabel Y (Citra perusahaan) adalah sebesar 21,955. Koefisien regresi $X$ sebesar 0,490 menyatakan bahwa setiap penambahan 1 angka dan terdapat perubahan variabel $\mathrm{X}$ (Brand ambassaddor) maka nilai dari variabel Y (Citra Perusahaan) bertambah sebesar 0,490. Koefisien regresi tersebut bernilai positif, sehingga dapat dikatakan bahwa arah pengaruh variabel $\mathrm{X}$ terhadap variabel $\mathrm{Y}$ adalah positif.

\section{Uji T}

Setelah diuji, nilai dari $t_{\text {tabel }}$ variabel $\mathrm{X}$ adalah 1,984 dan nilai $t_{\text {hitung }}$ variabel $\mathrm{X}$ adalah 7,064, maka $t_{\text {hitung }} \geq t_{\text {tabel }}$ yaitu $7,064 \geq 1,984$, dan nilai sig $<\alpha$ yaitu 0,000 $<0,05$. Hal ini dapat dikatakan bahwa hasil uji $\mathrm{T}$ pada variabel $\mathrm{X}$ adalah Ho ditolak dan Ha diterima, artinya terdapat pengaruh atau memiliki pengaruh antara brand ambassaddor Didi Kempot terhadap citra perusahaan Shopee.

\section{Simpulan}

Berdasarkan dari hasil penelitian, maka penelitian ini menghasilkan bahwa terdapat hubungan antara brand ambassaddor dengan citra perusahaan. Hubungan dalam penelitian ini dinyatakan sedang, karena nilai yang diperoleh dari uji korelasi pearson dalam penelitian ini sebesar 0,581 . Pengaruh dalam penelitian ini bernilai positif sehingga apabila ada peningkatan pada brand ambassaddor maka citra perusahaan juga meningkat. Hasil koefisien determinasi dalam penelitian ini yaitu sebesar 33,7\% yang memiliki arti bahwa kemampuan brand ambassdor dalam mempengaruhi citra perusahaan Shopee adalah lemah, karena nilai yang dimiliki dari koefisien determinasi mendekati angka nol, sehingga sisanya 66,3\% dipengaruhi oleh faktor lain.

Dengan demikian penelitian ini menyatakan Ho ditolak dan Ha diterima yang artinya terdapat pengaruh dari brand ambassaddor Didi Kempot terhadap citra perusahaan Shopee. Sehingga dalam penelitian ini Brand ambassaddor berpengaruh 
signifikan terhadap citra perusahaan Shopee, karena $t_{\text {hitung }} \geq t_{\text {tabel }}$ yaitu $7,064 \geq$ 1,984, dan nilai signifikan $<\alpha$ yaitu $0,000<0,05$.

\section{Ucapan Terima Kasih}

Penulis ingin menyampaikan ucapan terima kasih kepada semua individu baik orangtua, adik, sahabat-sahabat penulis dan responden yang telah membantu penulis untuk meluangkan waktu dan memberi dukungan hingga penelitian ini dapat diselesaikan dengan baik.

\section{Daftar Pustaka}

Creswell, John W. 2014. Research Design Pendekatan Kualitatif, Kuantitatif, dan Mixed. Yogyakarta: Pustaka Pelajar.

Poghosyan, A. (2015). Celebrity Endorsement as one of nowadays Major Ways to Influence Consumer Buying Behaviour. European Scientific Journal, 30-38.

Royan, Frans M. (2004). Marketing Selebrities. Jakarta: Media komputindo.

Soemirat, Soleh \& Ardianto, Elvinaro. (2007). Dasar-Dasar Public Relations. Bandung: Rosdakarya.

Sugiyono. (2017). Metode Penelitian Kuantitatif, Kualitatif, dan R\&D. Bandung: Alfabeta. 